\title{
Evaluation of Closure versus Non-closure of Vaginal Vault after Non-descent Vaginal Hysterectomy
}

\author{
Saha M', Rahman RRB ${ }^{2}$, Ara $\mathbf{G}^{3}$, Rahman $\mathrm{F}^{4}$, Jahan $\mathrm{R}^{5}$
}

Conflict of Interest: None

Received: 31.12 .2019

Accepted: 05.03 .2020

www.banglajol.info/index.php/JSSMC

\section{Key Words:}

Vaginal, hysterectomy, vault, haematoma, ultrasound.

\begin{abstract}
Introduction: Non-descent vaginal hysterectomy has been considered a valid alternative to the abdominal approach and is also preferred for benign uterine diseases without descent of uterus because it is associated with fewer complications. Vaginal vault is the enlargement of the internal end of the vagina which is usually closed during vaginal hysterectomy. This study was done to see the outcome of vault closure versus non-closure in non-descent vaginal hysterectomy in non-prolapsed uterus.
\end{abstract}

Methods: This prospective study was done in Obstetrics and Gynae Department, Sir Salimullah Medical College and Mitford Hospital during the period of July 2011 to December 2011. A total number of 50 patients with benign gynecological disorders without descent of uterus who admitted for hysterectomy were enrolled in this study. Among them, 25 patients had the vault close (group I) whereas 25 patients had an open vault(group11). Indication for hysterectomy, complications, blood transfusion, hospital stay (day) and histopathological findings were assessed for both groups. Statistical analyses of the results were obtained by using window based computer software devised with Statistical Packages for Social Sciences (SPSS-20).

Results: Majority of the patients was found in the age group of 41-45 years in both groups, which was 12(48.0\%) in Group I and 18(72.0\%) patients in Group II. Blood transfusion was needed in 5(20.0\%) and in 6(24.0\%) in Group I and Group II respectively. Post operative complications after 15 days of follow-up, pelvic abscess was found $4.0 \%$ in Group I \& not found in Group II. UTI was not found in Group I but 4.0\% found in Group II.

Conclusion: Outcomes were almost similar in both procedure. Ultimately the study did not show any significant difference between either group.

[J Shaheed Suhrawardy Med Coll 2020; 12(1): 45-49] DOI: https://doi.org/10.3329/jssmc.v12i1.51618

\section{Introduction}

Vaginal hysterectomy has been considered a valid alternative to the abdominal approach and studies have shown it to be associated with fewer complications ${ }^{1}$ and a shorter recovery period and hospital stay than the abdominal procedure. It is preferred in high risk cases like obesity and is cosmetic. ${ }^{2}$

1. Dr. Mousumi Saha, Assistant Professor (Obs \& Gynae), Institute of Child and Mother Health (ICMH), Matuail, Dhaka-1362.

2. Prof. Ratu Rumana Binte Rahman, Former Professor (Obs \& Gynae), Sir Salimullah Medical College and Mitford Hospital, Dhaka.

3. Prof. Gulshan Ara, Professor (Obs \& Gynae), Enam Medical College, Savar, Dhaka.

4. Dr. Florida Rahman, Assistant Professor (Obs \& Gynae), Dhaka Medical College Hospital, Dhaka,

5. Dr. Raunak Jahan, Assistant Professor (Obs \& Gynae), Shaheed Suhrawardy Medical College, Dhaka

Correspondence: Dr. Mousumi Saha, Assistant Professor (Obs \& Gynae), Institute of Child and Mother Health (ICMH), Matuail, Dhaka-1362, Mobile: +8801711311425, E-mail: sahamousumi488@gmail.com
The reasons which indicate that vaginal route is preferential for benign uterine diseases like fibroid uterus, DUB, adenomyosis, PID because this procedure need not make incision in the abdominal wall which may produce some consequences like pain, sepsis, adhesions, laparocele, scars, manipulation of bowel. The vaginal procedure causes early return of bowel function, a shorter operative time, fewer risk of ureteral \& intestinal harm, less surgical bleeding, the possibility of applying loco regional anesthesia, less pain and early discharges..$^{11} \mathrm{It}$ is possible to convert the procedure to abdominal route at any time. ${ }^{11}$

The operation of vaginal hysterectomy is quick and no advanced equipment is needed. In addition, the operation can be performed successfully even in women with an enlarged uterus, nulliparity or a history of pelvic surgery. ${ }^{11-14}$ The need for oophorectomy should not be considered a contraindication. ${ }^{6}$ 
The vault closure of the procedure causes ischemia, adhesions, haematoma $\&$ sometimes causes formation of granulation tissue. ${ }^{9}$ Non- closure causes less ischemia, less adhesion, less haematoma formation, no formation of granulation tissue. On the other hand it facilitates drainage of the blood \& exudates. ${ }^{9}$ So non-closing of the vault is preferable method. In case of non-closure of the vault securing of vaginal angles are necessary as they are most notorious oozers in the post operative period. Mc Call culdoplasty at the time of vaginal hysterectomy is a recommended measure to prevent enterocele formation. Suturing the cardinal and uterosacral ligaments to the vaginal cuff at the time of hysterectomy is a recommended measure to avoid vault prolapse. ${ }^{10}$

Regarding non-closure of vault in 1980, Harold Ellis showed that closing the peritoneum at the end of abdominal surgery is not necessary. ${ }^{5}$ The thin peritoneum, unlike skin cannot be adapted by placing its ends together. ${ }^{5}$ Vascular bridges over peritoneal sutures are a focus for ischaemia $\&$ adhesions. ${ }^{6}$ When peritoneum is left open, the coelum cells will produce a new peritoneum. ${ }^{6}$ Indeed, leaving peritoneum open in a caesarean section proved to cause less adhesions than when it was closed. ${ }^{7}$ It was also shown that the peritoneum closure is not necessary for vaginal hysterectomy. ${ }^{7}$ Another advantage of leaving peritoneum open is that: in addition to drainage by blood and lymph channels, the fluid/blood can be drained out through open peritoneum. ${ }^{8}$

Laparoscopic assisted vaginal hysterectomy (LAVH), although constantly gaining ground is associated with higher costs, ${ }^{15}$ and longer duration of operation, and involves a large number of specially trained personnel. ${ }^{3}$ With increasing concern over the containment of health care costs, there is a need for expanding the indications for performing hysterectomies via the vaginal nonlaparoscopic method, ${ }^{16}$ instead of confining it to the conventional uterine descent.

Therefore, keeping all above mentioned points this study designed to see the outcome of vault closure versus nonclosure in non-descent vaginal hysterectomy in nonprolapsed uterus in a tertiary hospital in Bangladesh.

\section{Materials and Methods}

This comparative study was done in the department of Obstetrics and Gynaecology of Sir Salimullah Medical College and Mitford Hospital (SSMC\& MH), Dhaka, Bangladesh during the period from July 2011 to December 2011. It was carried out on 50 women admitted requiring hysterectomy for benign gynaecological disorders without prolapse such as Dysfunctional Uterine Bleeding (DUB), Fibroid uterus, adenomyosis, PID, benign ovarian cysts less than $8 \mathrm{~cm}$ in size. Out of which in 25 cases where vault was kept close (vault closure) was considered as group I and in 25 cases where vault was kept open (vault non-closure) was considered as group II. Patients having uterine size not exceeding 14 weeks of gravid uterus, adequate vaginal access and uterine mobility and laxity of the pelvic muscles were enrolled in this study. Patients with uterine prolapse, endometriosis, severely restricted mobility of uterus, complex adnexal mass and suspicion of malignancy were excluded from the study.

Due permission was taken from ethical committee of Sir Salimullah Medical college Mitford Hospital, Dhaka. A detailed history covering all relevance to this study was taken, general examination, menstrual history, obstetric history, investigation reports, type of anesthesia, operation time, per operative complications, amount of blood loss, postoperative complications and histopathological reports were recorded. All data were analyzed by using computer based SPSS (version 22.0) programme. Statistical analysis was performed, categorical variables were presented in the form of frequency and percentage and analysis of association was made using chi-square test (c2) of significance. Quantitative data were presented in the form of mean and standard deviation. Comparison of means made by using student's t-test, a p-value less $<0.05$ were considered statistically significant.

\section{Results}

The mean age was found $44.84 \pm 4.41$ years in Group I and $43.04 \pm 2.3$ years in Group II. Most of the patients were multi para in both groups, which were $23(92.0 \%)$ and $22(88.0 \%)$ in group I and group II respectively. The mean operation time was found $50.8 \pm 5.89$ minutes in Group I and 49.6 \pm 5.58 minutes in group II. The mean weight of uterus was found $212.27 \pm 63.01 \mathrm{gm}$ in group I and $172.5 \pm 33.42 \mathrm{gm}$ in group II. Regarding post operative complication after 15 days only pelvic abscess was found $1(4 \%)$ in group I and UTI was found $1(4 \%)$ in group II.

Table I

\begin{tabular}{lccc}
$\begin{array}{l}\text { Distribution of the study patients according to size of } \\
\text { uterus }(n=50)\end{array}$ \\
Size of uterus & $\begin{array}{c}\text { Group I } \\
(\mathrm{n}=25)\end{array}$ & $\begin{array}{c}\text { Group II } \\
(\mathrm{n}=25)\end{array}$ & $\begin{array}{c}P \\
\text { value }\end{array}$ \\
\hline Upto 8 weeks & $3(12 \%)$ & $2(8 \%)$ & \\
$8-10$ weeks & $18(72 \%)$ & $19(76 \%)$ & 0.973 \\
$10-12$ weeks & $3(12 \%)$ & $3(12 \%)$ & \\
$12-14$ weeks & $1(4 \%)$ & $1(4 \%)$ & \\
\hline
\end{tabular}


Table II

\begin{tabular}{lccc}
\multicolumn{4}{c}{$\begin{array}{c}\text { Distribution of the study patients according to } \\
\text { indication for hysterectomy }\end{array}$} \\
$\begin{array}{lccc}(n=50) . \\
\text { Indication for } \\
\text { hysterectomy }\end{array}$ & $\begin{array}{c}\text { Group I } \\
(\mathrm{n}=25)\end{array}$ & $\begin{array}{c}\text { Group II } \\
(\mathrm{n}=25)\end{array}$ & $\begin{array}{c}P \\
\text { value }\end{array}$ \\
\hline DUB & $10(40 \%)$ & $9(36 \%)$ & 0.770 \\
Fibroid uterus & $10(40 \%)$ & $10(40 \%)$ & 1.000 \\
Adenomyosis & $4(16 \%)$ & $3(12 \%)$ & 0.500 \\
Adnexal mass & $1(4 \%)$ & $2(8 \%)$ & 0.500 \\
PID & $0(0 \%)$ & $1(4 \%)$ & 0.500 \\
\hline
\end{tabular}

\section{Table III}

Distribution of the study patients according to blood loss during operation $(n=50)$.

\begin{tabular}{lccc}
$\begin{array}{l}\text { Estimated blood loss } \\
\text { during operation }(\mathrm{ml})\end{array}$ & $\begin{array}{c}\text { Group I } \\
(\mathrm{n}=25)\end{array}$ & $\begin{array}{c}\text { Group II } \\
(\mathrm{n}=25)\end{array}$ & $\begin{array}{c}P \\
\text { value }\end{array}$ \\
\hline$\leq 100$ & $22(88 \%)$ & $25(100 \%)$ & \\
$>100$ & $3(12 \%)$ & $0(0 \%)$ & \\
Mean \pm SD & $80.4 \pm 36.11$ & $68.4 \pm 12.48$ & 0.12 \\
Range(min-max) & $(40-200)$ & $(50-100)$ & \\
\hline
\end{tabular}

\section{Table IV}

Distribution of the study patients according to post operative macroscopic measurement of uterus(weight in gm) $(n=50)$.

\begin{tabular}{lccc}
$\begin{array}{l}\text { Uterus size } \\
\text { (weight }) \text { gm }\end{array}$ & $\begin{array}{c}\text { Group I } \\
(\mathrm{n}=25)\end{array}$ & $\begin{array}{c}\text { Group II } \\
(\mathrm{n}=25)\end{array}$ & $\begin{array}{c}P \\
\text { value }\end{array}$ \\
\hline $100-200$ & $15(60 \%)$ & $21(84 \%)$ & \\
$201-300$ & $6(24 \%)$ & $3(12 \%)$ & \\
$>300$ & $4(16 \%)$ & $1(4 \%)$ & \\
Mean \pm SD & $212.27 \pm 63.01$ & $172.5 \pm 35.42$ & 0.011 \\
Range(min-max $)$ & $(150-400)$ & $(100-260)$ & \\
\hline
\end{tabular}

Table V

Distribution of the study patients according to per operative complications $(n=50)$.

\begin{tabular}{lccc}
$\begin{array}{l}\text { Per operative } \\
\text { complications }\end{array}$ & $\begin{array}{c}\text { Group I } \\
(\mathrm{n}=25)\end{array}$ & $\begin{array}{c}\text { Group II } \\
(\mathrm{n}=25)\end{array}$ & $P$ value \\
\hline Hemorrhage & $1(4 \%)$ & $0(0 \%)$ & 0.312 \\
Bladder injury & $0(0 \%)$ & $1(4 \%)$ & 0.312 \\
\hline
\end{tabular}

Table VI

Distribution of the study patients according to post operative complications $(n=50)$.

\begin{tabular}{lccc}
$\begin{array}{l}\text { Post operative } \\
\text { complications } \\
\text { after 15 days }\end{array}$ & $\begin{array}{c}\text { Group I } \\
(\mathrm{n}=25)\end{array}$ & $\begin{array}{c}\text { Group II } P \text { value } \\
(\mathrm{n}=25)\end{array}$ \\
\hline Pelvic abscess & $1(4 \%)$ & $0(0 \%)$ & 0.312 \\
UTI & $0(0 \%)$ & $1(4 \%)$ & 0.312 \\
\hline
\end{tabular}

\section{Discussion}

Vaginal hysterectomy has certain advantages over abdominal hysterectomy. ${ }^{17}$ Vaginal route is associated with lower mortality, lower risk of operative haemorrhage, less thromboembolic disease and fewer blood transfusions. Vaginal hysterectomy facilitates a shorter hospital stay, quicker postoperative recovery and avoids incision, thus decreasing postoperative discomfort. ${ }^{18}$ For these reasons, adoption of vaginal hysterectomy, as a routine procedure, would enable the surgical throughput in a unit to be maintained on a smaller bed compartment.

In this current study majority of the patients was found in 5 th decade in both groups. Miskry and Magos, ${ }^{2}$ have shown that in their series, the mean age of the patients having benign gynecological disorders without prolapse were 42.0 years varied from 36 to 49 years and 41.4 years varied from 30 to 52 years respectively, which is closely resembled with the present study groups. Similarly, Hwang et al. ${ }^{12}$ showed that the mean $( \pm \mathrm{SD})$ age was $44 \pm 5.0$ years in group I and $45 \pm 4.4$ years in group II. Similar identical mean age were also observed by Harmanli et al. $7,12,19$ of the patients having benign gynecological disorders without prolapse and thus, support the present study. On the other hand, Benassi et al. ${ }^{11}$ has observed higher mean age in their study patients, which was $48 \pm$ 5.3 years and $47 \pm 5.1$ years in group I and group II respectively. Similarly, higher mean age also obtained by Agostini et al. ${ }^{20}$ where the authors found the mean age was $50 \pm 8.5$ years in group I and $49 \pm 11$ years in group I. Davies et al. ${ }^{21}$ showed the mean age was 53.3 years and 52.3 years in group I and group II respectively. The higher age range maybe due to geographical variation, genetic cause and racial influences. Davies et al. ${ }^{21}$ have shown previous pelvic surgery was $23.7 \%$ in group I and $28.0 \%$ in group II, which is comparable with the current study.

Regarding the parity Miskry and Magos, ${ }^{2}$ have shown multi para was predominant in their study, which were $88.2 \%$ in group I and $72.3 \%$ in group II. Similar findings were obtained by Harmanli et al. ${ }^{7}$, and Benassi et al. ${ }^{11}$ in 
their series of studies. The results of the present study closely resemble with the above studies.

Miskry and Magos, ${ }^{2}$ have shown that the mean uterus size was 6.9 weeks in group I and was 7.8 weeks in group II. Davies et al. ${ }^{21}$ showed that the mean uterus size was 6.0 weeks and was 8.10 weeks in group I and group II respectively. The above findings are comparable with the present study.

Regarding the indications for hysterectomy in this study it was observed that DUB and fibroid uterus were more frequent in both groups, DUB was found in $40.0 \%$ Group I and in $36.0 \%$ Group II. Fibroid uterus was observed $40.0 \%$ and $40.0 \%$ in Group I and Group II respectively. Adenomyosis was $16.0 \%$ in Group I and $12.0 \%$ in Group II. Adnexal masses were found $4.0 \%$ and $8.0 \%$ in Group I and Group II respectively. PID was not observed in Group I but it was $4.0 \%$ in Group II, which was not statistically significant $(p>0.05)$ between two groups. Similarly, Agostini et al. ${ }^{20}$ showed fibroid uterus $44.2 \%$ in group I and $40.3 \%$ in group II, adenomyosis was found $15.4 \%$ and $18.1 \%$ in group I and group II respectively. Similar observations regarding the indication for hysterectomy were also made by Davies et al. (1998) and ${ }^{19}$.

Massive blood loss was observed by Miskry and Magos, ${ }^{2}$ where they found the mean estimated blood loss $(\mathrm{mL})$ was $353 \mathrm{ml}$ with ranged from $100 \mathrm{ml}$ to $1000 \mathrm{ml}$ in group I and $431 \mathrm{ml}$ with range from $50-1500 \mathrm{ml}$, this may be due associated co-morbidity condition of their study patients.

Miskry and Magos, ${ }^{2}$ found the mean weight of uterus was $150 \mathrm{gm}$ with range from $70-385 \mathrm{gm}$ in group I and 218 gm with 20841 gm in group I and group II respectively, which support the current study. Benassi et al. ${ }^{11}$ have shown the mean weight of uterus was $380 \pm 165 \mathrm{gm}$ in group I and $436 \pm 171 \mathrm{gm}$ in group II, which is higher in comparison to the current study. Similarly, higher mean weight of uterus was also obtained by Agostini et al. ${ }^{20}$ whereas the investigators found the mean weight of uterus was $347.35 \pm 242.3 \mathrm{gm}$ and $333.9 \pm 235.01 \mathrm{gm}$ in group I and group II respectively. Similar observations made by Unger, ${ }^{19,7}$ which may be due to their higher body surface area in their study patients.

Regarding the per-operative complications of current series, hemorrhage was found $4.0 \%$ in Group I but not found in Group II. Bladder injury was found $4.0 \%$ in Group II but not found in Group I, which was not statistically significant (p.0.05) between two groups. In a study, Agostini et al. ${ }^{20}$ showed haemorrhage $7.69 \%$ and $1.71 \%$ in group I and group II respectively. Harmanli et al. ${ }^{7}$ found bladder injury $1.1 \%$ in group I and $1.5 \%$ in group II. The above authors findings are consistent with the current study.
Regarding post operative complications, it was observed in this current study that pelvic abscess was found $4.0 \%$ in Group I \& not found in Group II and UTI was not found in Group I but found $4.0 \%$ in Group II after 15 days of operation. No complication was seen in the cases in followup after 45 days of operation in both groups. Harmanli et al. ${ }^{7}$ observed urinary tract infection $5.4 \%$ and $6.5 \%$ in group I and group II respectively, which is comparable with the current study.

Benassi et al. ${ }^{11}$ observed $13.3 \%$ and $16.8 \%$ patients received blood trasnfusion. I another study, Harmanli et al. $^{7}$ found $9.2 \%$ and $11.5 \%$ patients required blood transfusion, which are comparable with the current study.

Benassi et al. ${ }^{11}$ observed the mean duration of hospital stay was $3.4 \pm 0.7$ days and $4.3 \pm 1.5$ days in group I and group II, which is comparable with the current study. Similarly, Unger, ${ }^{19}$ have shown the mean duration of hospital stay was $1.9 \pm 0.6$ days in group I and $1.8 \pm 0.9$ days in group II respectively.

Regarding the histopathological findings it was observed in this present series that myoma of uterus, secretory phase of uterus (DUB) and adneomyosis were more common findings, where myoma of uterus was found $40.0 \%$ in Group I and $40.0 \%$ in Group II. Secretory phase of uterus (DUB) was found $24.0 \%$ and $28.0 \%$ in Group I and Group II respectively. Adneomyosis was found $16.0 \%$ in Group I and $8.0 \%$ in Group II.

\section{Conclusion}

The present study concludes that patients requiring hysterectomy for benign gynaecological disorders without prolapse may be offered the option of non- descent vaginal hysterectomy which has quicker recovery, shorter hospitalization, lesser operative and postoperative morbidity. Vault closure of the procedure causes ischemia, adhesion, haematoma \& sometimes causes formation of granulation tissue. Non- closure causes less ischemia, less adhesion, less haematoma formation, no formation of granulation tissue and it facilitates drainage of the blood $\&$ exudates. So non - closure of the vault is preferable method. But in this study both the procedures of closure and non-closure technique outcomes were almost similar regarding post-operative complications, hospital stay, per operative blood loss. This study did not show any significant difference between either group.

\section{References}

1. Dicker RC, Greenspan JR, Strauss LT, Cowart MR, Scally MJ, Peterson HB, DeStefano F, Rubin GL, Ory HW. Complications of abdominal and vaginal hysterectomy among women of reproductive age in the United States: the collaborative review of sterilization. American Journal of Obstetrics and Gynecology. 1982 Dec 1;144(7):841-8. 
2. Miskry T, Magos A. Randomized, prospective, double blind comparison of abdominal and vaginal hysterectomy in women without uterovaginal prolapse. Acta obstetricia et gynecologica Scandinavica. 2003 Apr 1;82(4):351-8.

3. Davies A, Vizza E, Bournas N, O’Connor H, Magos A. How to increase the proportion of hysterectomies performed vaginally. American journal of obstetrics and gynecology. 1998 Oct 31;179(4):1008-12.

4. Magos A, Bournas N, Sinha R, Richardson RE, O'connor H. Vaginal hysterectomy for the large uterus. BJOG: An International Journal of Obstetrics \& Gynaecology. 1996 Mar 1;103(3):24651 .

5. Doucette, R.C., Sharp, H.T. and Alder, S.C., 2001. Challenging generally accepted contraindications to vaginal hysterectomy. American journal of obstetrics and gynecology, 184(7), pp.1386-1391.

6. Sheth SS. Adnexectomy for benign pathology at vaginal hysterectomy without laparoscopic assistance. BJOG: An International Journal of Obstetrics \& Gynaecology. 2002 Dec $1 ; 109(12): 1401-5$

7. Harmanli OH, Gentzler CK, Byun S, Dandolu V, Grody MH. A comparison of abdominal and vaginal hysterectomy for the large uterus. International Journal of Gynecology \& Obstetrics. 2004 Oct 1;87(1):19-23.

8. Teoh TG. Outcome of vaginal hysterectomy for the undescended and enlarged uterus - a preliminary report. The Medical journal of Malaysia. 1996 Dec;51(4):415-9.

9. Thomson, A.J. and Farquharson, R.G., 2000. Vault haematoma and febrile morbidity after vaginal hysterectomy. Hospital medicine (London, England: 1998), 61(8), pp.535-8.

10. McCall ML. Posterior Culdeplasty: Surgical correction of enterocele during vaginal hysterectomy; a preliminary report. Obstetrics \& Gynecology. 1957 Dec 1;10(6):595-602.

11. Benassi L, Rossi T, Kaihura CT, Ricci L, Bedocchi L, Galanti B, Vadora E. Abdominal or vaginal hysterectomy for enlarged uteri: a randomized clinical trial. American journal of obstetrics and gynecology. 2002 Dec 31;187(6):1561-5.

12. Hwang JL, Seow KM, Tsai YL, Huang LW, Hsieh BC, Lee C. Comparative study of vaginal, laparoscopically assisted vaginal and abdominal hysterectomies for uterine myoma larger than 6 $\mathrm{cm}$ in diameter or uterus weighing at least $450 \mathrm{~g}$ : a prospective randomized study. Acta obstetricia et gynecologica Scandinavica. 2002 Dec 1;81(12): 1132-8

13. Deval B, Rafii A, Soriano D, Samain E, Levardon M, Darai E. Morbidity of vaginal hysterectomy for benign tumors as a function of uterine weight. The Journal of reproductive medicine. 2003 Jun;48(6):435-40.

14. Agostini A, Bretelle F, Cravello L, Maisonneuve AS, Roger V, Blanc B. Vaginal hysterectomy in nulliparous women without prolapse: a prospective comparative study. BJOG: An International Journal of Obstetrics \& Gynaecology. 2003 May $1 ; 110(5): 515-8$.

15. Meikle SF, Nugent EW, Orleans M. Complications and recovery from laparoscopy-assisted vaginal hysterectomy compared with abdominal and vaginal hysterectomy. Obstetrics \& Gynecology. 1997 Feb 1;89(2):304-11.

16. Mazdisnian F, Kurzel RB, Coe S, Bosuk M, Montz F. Vaginal hysterectomy by uterine morcellation: an efficient, non-morbid procedure. Obstetrics \& Gynecology. 1995 Jul 1;86(1):60-4.

17. Thomson AJ, Sproston AR, Farquharson RG. Ultrasound detection of vault haematoma following vaginal hysterectomy. BJOG: An International Journal of Obstetrics \& Gynaecology. 1998 Feb $1 ; 105(2): 211-5$.

18. Gitsch G, Berger E, Tatra G. Trends in thirty years of vaginal hysterectomy. Surgery, gynecology \& obstetrics. 1991 Mar;172(3):207-10.

19. Unger JB. Vaginal hysterectomy for the woman with a moderately enlarged uterus weighing 200 to 700 grams. American journal of obstetrics and gynecology. 1999 Jun 30;180(6):1337-44.

20. Agostini A, Bretelle F, Cravello L, Maisonneuve AS, Roger V, Blanc B. Vaginal hysterectomy in nulliparous women without prolapse: a prospective comparative study. BJOG: An International Journal of Obstetrics \& Gynaecology. 2003 May $1 ; 110(5): 515-8$

21. Davies A, Vizza E, Bournas N, O'connor H, Magos A. How to increase the proportion of hysterectomies performed vaginally. Female Pelvic Medicine \& Reconstructive Surgery. 1999 Mar $1 ; 5(2): 123$. 